\title{
A framework for crafting and implementing a congregational strategy in the local congregations of the Reformed Churches of South Africa
}

\begin{abstract}
Authors:
Aldeon B. Grobler ${ }^{1}$

J. Louw van der Walt ${ }^{1}$

Barend J. de Klerk ${ }^{2}$

Affiliations:

${ }^{1}$ Potchefstroom Business School, North-West University, Potchefstroom Campus, South Africa

${ }^{2}$ School of Ecclesiastical Science, North-West University, Potchefstroom Campus, South Africa

Correspondence to: Louw van der Walt

Email:

louw.vanderwalt@nwu.ac.za

Postal address:

PO Box 21199, Noordbrug

2522, South Africa

Dates:

Received: 09 June 2011

Accepted: 02 Sept. 2011

Published: 12 Dec. 2012

How to cite this article:

Grobler, A.B., Van der

Walt, J.L. \& De Klerk, B.J.,

2012, 'A framework for

crafting and implementing

a congregational strategy in

the local congregations of

the Reformed Churches of

South Africa', In die Skriflig/

In Luce Verbi 46(2), Art \#103,

10 pages. http://dx.doi.

org/10.4102/ids.v46i2.103
\end{abstract}

(C) 2012. The Authors.

Licensee: AOSIS

OpenJournals. This work

is licensed under the

Creative Commons

Attribution License.
The church is not like any other institution or organisation in society. Although the church is primarily invisible and spiritual, it is a visible organisation in the world, and it spans across borders of nations, languages and countries. John Calvin strongly rejected the notion that the church is only a spiritual organisation of which the visible administrative side is downplayed. The fellowship of the church must not only be seen as a mystical relation with Jesus Christ. During 2010, an empirical study was done on the extent to which congregations of the Reformed Churches of South Africa (RCSA) adhere to the request to have a well-designed congregational strategy. The knowledge gained from a literature study on the science of Strategic Management and the results of the empirical study was combined into a framework for crafting and executing a congregational strategy. This framework can be used by congregational leaders to guide them through their own process of crafting and executing their unique congregational strategy. The research was concluded with a recommendation that the Theological School of the RCSA should consider including a course on Strategic Management in the training syllabus of aspiring ministers. Considering that Strategic Management is a specialised management science, and external Strategic Management consultants tend to be expensive, the research also recommended that the Administrative Bureau of the RCSA consider employing their own Strategic Management consultant for the RCSA with the specific assignment of assisting and guiding all congregations with their congregational strategy.

'n Raamwerk vir die ontwerp en implementering van 'n gemeentestrategie in die plaaslike gemeentes van die Gereformeerde Kerke in Suid-Afrika. ' $n$ Kerk is 'n unieke organisasie. Die kerk is primêr onsigbaar en geestelik van aard. Tog funksioneer dit as 'n instituut in die wêreld en moet dit doelmatig en doeltreffend bestuur word, ten einde alles ordelik te laat verloop en doelgerig te laat funksioneer. Johannes Calvyn het die idee dat 'n gemeente slegs 'n geestelike instelling is, waarvan die sigbare administratiewe deel as onbelangrik afgemaak word, verwerp. 'n Empiriese studie is gedurende 2010 onderneem om vas te stel tot watter mate gemeentestrategieë wel in die Gereformeerde Kerke in Suid-Afrika (GKSA) opgestel en uitgevoer word. Die kennis wat ingewin is met die empiriese studie is gekombineer met 'n literatuurstudie oor die vakgebied van Strategiese Bestuur, en 'n raamwerk vir die ontwerp en implementering van 'n gemeentestrategie is daargestel. Hierdie raamwerk kan deur gemeenteleiers gebruik word in die ontwerp en implementering van hulle gemeente se strategie. Die navorsing sluit af met die aanbeveling dat daar oorweging geskenk moet word om ' $n$ kursus in strategiese bestuur in die opleidingsillabus van teologiese studente in te sluit. ' $n$ Verdere aanbeveling is gemaak dat, weens die gespesialiseerde aard en koste aan eksterne Strategiese Bestuurskonsultante verbonde, die Administratiewe Buro van die GKSA oorweging behoort te skenk om hulle eie konsultant in diens te neem. Die opdrag moet wees om gemeentes van die GKSA by te staan in die ontwerp en implementering van die gemeentestrategie.

\section{Introduction}

The church differs from any other organisation or business in the community. It is unique in that it belongs to Jesus Christ, who is the head of the church (Eph 1:22). God's people are not merely members of a church, but ligaments who support and grow the entire body (Eph 4:16). Although the church is unique and God-given, God uses ordinary people (1 Cor 3:5) to serve his church, and to grow (Mt 28:19) and maintain (Mt 28:20) it.

To view the church as equal to any other organisation in society that must be organised and managed is incorrect (Vergeer 2000: [point 2.4.1]). The church is primarily invisible and spiritual by nature. The institutional character of a congregation should never be the primary focus (Van Wyk 2001:39). 
There are profound differences between a business and a congregation. However, a congregation exists in the same world as other organisations, is confronted by the same political, economical, environmental and social factors, and has ordinary people as members. Thus, there are also definite similarities between the management of the activities of a congregation and a normal worldly organisation.

The starting point for the theological framework of this article is that Scripture is the primary source of knowledge for the interpretation of reality and thus also for a congregational strategy in the local congregations of the Reformed Churches of South Africa (RCSA). The authors follow a theocentric viewpoint on reality, because God is involved in reality in a Trinitarian way. We acknowledge that there is always an element of the presence of God and that this will also play a part in the presentation of the results of this research. In this article the method of Osmer (2008) is taken into consideration. He stated that for research in Practical Theology, the following four tasks are very important: 'The descriptive task ... the interpretative task ... the normative task ... the pragmatic task' (Osmer 2008:4-11).

\section{Problem statement}

At the three-yearly synod of the Reformed Churches of South Africa (RCSA) which was held in 2000, a report was tabled under the heading of 'Preservation and Growth of the Church' (Vergeer 2000). The report clearly states that all local congregations should develop and implement a congregational strategy that is applicable to their own unique environment. The congregational strategy's main purpose must be to guide the congregation to fulfil its biblical purpose and should not only have growth in membership as a main driving force.

The question arises as to how many of the congregations of the RCSA were able to effectively put a congregational strategy in place. The purpose of this article is to evaluate the state of strategic planning in the local congregations of the RCSA and to make recommendations regarding the topic. This entails an empirical study regarding congregational strategies in the RCSA as well as a literature study of the management science of Strategic Management.

\section{The science of Strategic Management}

Crafting and implementing of strategy, or Strategic Management, is not a new concept. In reading how Nehemiah planned and executed the rebuilding of the wall of Jerusalem, the principles of Strategic Management are evident. However, it was during the 1990s that it became a scientific field of study that is practised widely today, not only in business organisations, but also in non-profit institutions such as government institutions, educational institutions, libraries and churches (David 2005:185). Although Strategic
Management is a risky business with no guarantees (Ungerer 2009:14), an organisation without a strategy is like a ship without a rudder (Thompson, Strickland \& Gamble 2007:2). Many definitions of Strategic Management can be found in dictionaries, encyclopaedias and books on management, but it can be summarised as follows: the process whereby an organisation assesses its current position, decides on where it needs to be in the future, designs the action plan to get there and then leads the organisation on the chosen path (Grobler 2010:18). From various descriptions of Strategic Management, the following are the most important components:

- Strategic Management is a scientific process consisting of analysis, decisions and actions (Dess, Lumpkin \& Eisner 2008:8).

- Someone who does not have clear goals does not need a strategy. Setting clear goals and crafting plans on how to achieve the goals are fundamental to Strategic Management (Wiebes, Marc, Keibek \& Witteveen 2007:xiv). The goals normally entail ensuring the sustainability of an organisation, such as creating a competitive advantage (Thompson et al. 2007:6).

- The process of Strategic Management has various phases. At a high level, there are two phases, namely, crafting or formulating the strategy and the execution and evaluation of the strategy (David 2005:5).

- Strategic management not only focuses on achieving short-term targets, but also on incorporating long-term perspectives (Dess et al. 2008:8).

- Strategic management transcends all functional areas of an organisation and integrates their respective goals (Wiebes et al. 2007:xiv). Strategic management requires managers to take an integrative view of the organisation and assess how all of the functional areas and activities fit together to help the organisation achieve its goals and objectives (Dess et al. 2008:22).

- Developing an effective strategy requires leadership to apply several lenses simultaneously to look at the organisation. A one-sided glance at the organisation will create mistakes or the loss of major opportunities (Stern \& Deimler 2006:193).

- Strategic management focuses on effectiveness (doing the right things) as well as efficiency (Dess et al. 2008:10).

In summary, the process can be explained in the following manner: strategic Management consists of the crafting or formulation of an entity's strategy as well as the implementation or execution of the formulated strategy. Strategy formulation entails deciding where the organisation currently is and where the organisation should be in the future. Strategy implementation encompasses deciding how to get the organisation from where it currently is to where it should be in the future (Thompson et al. 2007:7).

In Figure 1, the process of crafting and executing strategy is summarised as a five-phase process (Thompson et al. 2007:20). 


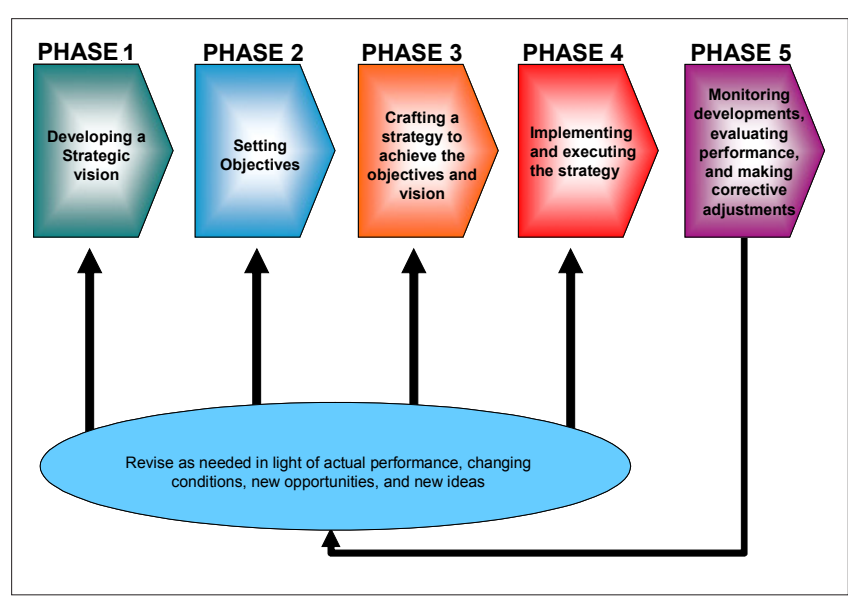

Source: Thompson, A.A., Strickland, A.J. \& Gamble, J.E., 2007, Crafting and executing strategy: The quest for competitive advantage, 15th edn., McGraw-Hill, New York.

FIGURE 1: The strategy-making, strategy-executing process.

\section{Phase 1: Developing a strategic vision}

A clearly-articulated vision communicates the organisation's aspirations for the future, and helps to steer all the energy and resources into a common direction. The importance of a clear vision of the future is highlighted in Proverbs 29:18 where it is stated that without a vision, people perish.

\section{Phase 2: Setting of objectives, which convert the vision into specific performance targets}

Objectives function as yardsticks for measuring how well the organisation is doing (Thompson et al. 2007:29). This integrated set of objectives must be balanced between long-term (5 - 10 years into the future) and short-term (one to two years into the future) activities, as well as financial and strategic issues (Garrison, Noreen \& Brewer 2006:449). An organisation, whose objectives are solely based on, for example financial objectives, would not be sustainable.

\section{Phase 3: Crafting a strategy to achieve the objectives and vision}

Strategy-making is not a top management function, but must be as inclusive as possible. The strategies and plans of the various functions and departments must be horizontally aligned with each other and vertically aligned with the strategic objectives.

\section{Phase 4: Implementing and executing the strategy}

This phase entails the well-structured and managed execution of the various strategic plans. It is important that management ensures that the necessary resources, skills and expertise are ready and available for the successful implementation of the plans. Structures, policies and procedures must be changed if they do not support the plans.

\section{Phase 5: Monitoring developments, evaluating performance and making corrective adjustments}

This phase entails continuous measuring and monitoring of the execution of the strategic plans. An organisation's direction, objectives, strategies or plans have to be revised continuously if changes in the external or internal conditions warrant it.

\section{Congregational strategy in the local congregations of the RCSA}

\section{The need for a congregational strategy}

Although the church is primarily invisible and spiritual, it is a visible organisation in the world, and it spans across borders of nations, languages and countries. John Calvin strongly rejected the notion that the church is only a spiritual organisation of which the visible administrative side is downplayed (Smit 2008:305). The fellowship of the church must not only be seen as a mystical relation with Jesus Christ. The fellowship with other Christians must be 'lived out' and must be a visible and measurable attribute (Vorster 1996:52).

At the three-yearly synod of the RCSA, which was held in 2000, a report was tabled under the heading of 'Preservation and Growth of the Church' (Vergeer 2000). The report gave guidance to congregations regarding the strategies with which to address the conservation and building of the church. The report clearly states that all local congregations should develop and implement a congregational strategy that is applicable to their own unique environment (Vergeer 2000: [assignment 3, point 1.1]). Any church council that does not pay attention to the structured planning and systematic growth of the congregation must be rejected as not true to the Bible (Vergeer 2000: [assignment 3, point 2.4.15]). The congregational strategy's main purpose must be to guide the congregation to fulfil its biblical purpose and should not only have growth in membership as a main driving force. The fact that people are turning their backs on the mainstream churches, including the RCSA who is losing about 2000 members per year (J.L. van der Walt 2009:264), is an indication that it cannot be 'business as usual' with regard to the way forward (ibid.:267). Without a long-term strategy, a congregation could easily stagnate, and stagnation in a congregation should never be acceptable (Smit 2009:448). A congregation should be careful not only to focus on current issues, and should have a proper long-term plan and strategy in order to achieve its goals (Vergeer 2000: [assignment 3, point 2.4.6, 2.4.13, 2.4.14]). Van Rooy (2007:40) warns that a congregation is seeking its own destruction if its main purpose is to survive.

\section{State of congregational strategies in the local congregations of the RCSA}

During 2010, an empirical study was conducted regarding congregational strategies in the local congregations of the RCSA (Grobler 2010:125). A standardised questionnaire was developed for this purpose and was distributed to all RCSA congregations via e-mail or traditional mail. Information was gathered from these congregations regarding the existence of a congregational strategy, as well as their approach and application in crafting and executing their congregational strategy. From a population of 249 congregations, the overall response rate was $46 \%$. The response from the traditionally White congregations was 100 congregations out of a potential 
190 congregations, which represents a 53\% response rate. The response from the traditionally Black congregations was 15 congregations out of a potential of 59 congregations. This represents a $25 \%$ response rate from the traditional Black congregations.

Of the 115 responding congregations, 48 respondents (42\%) indicated that they have a process that can be defined as a Strategic Management plan and 67 respondents (58\%) indicated that they do not have a congregational strategy. The existence of congregational strategies was found in 55\% of metropolitan congregations, but only in $34 \%$ of congregations in large towns and rural areas (Grobler 2010:128). Of the 67 respondents who did not have a congregational strategy, 56 are of the opinion that there should be a congregational strategy, but a lack of knowledge and skills in the science of Strategic Management is the main reason for not having a congregational strategy in place (ibid.:130). The fact that $45 \%$ of the congregations that indicated that they do have a congregational strategy are not satisfied with the process further emphasises the need for knowledge and skills regarding crafting and executing a strategy (ibid.:148).

\section{Best practices found in congregational strategies}

Part of the empirical study was to determine and share best practices from congregations in their congregational strategy process. The best practices listed by the congregations during the empirical study were evaluated and found to be supported by the literature on Strategic Management (Grobler 2010:132). The most dominant best practices are listed below.

\section{Best practice 1}

Thorough self-examination energised congregations towards action. With an honest and diligent effort to determine the truth of the current situation, the right decisions about the future often become self-evident (Collins 2001:88). By looking honestly at the current state, those in leadership begin to identify aspects in the organisation that are not satisfactory and that need to be addressed in the strategy (Daniell 2004:11). Of the 48 congregations that implemented Strategic Management, 38 listed a thorough self-examination, as required in 2 Corinthians 13:5, as best practice in their Strategic Management process.

\section{Best practice 2}

Consensus has to firstly be reached about the congregation's vision in order to reduce time spent on debating and working on less important matters. A clearly-articulated vision communicates any organisation's aspirations and helps steer the energy of an organisation's personnel in a common direction (Thompson et al. 2007:20). Warren (2007:56) indicates that a vision helps prevent congregation members from wasting endless time and energy debating small and less important things, as they have the all-important vision keeping them focussed. A vision is necessary in order for all in the congregation to know and understand where the congregation is going to in future (Kruger 2007:61). Without a vision a congregation runs the risk of becoming disorderly, as members and activities might work against each other. Burger (1999:45) emphasises that a congregation should find its vision from God, through prayer and Bible study. Finding the congregation's vision is a theoretically-sound starting point for a congregational strategy.

\section{Best practice 3}

A proper scientific analysis of their environment contributed to the congregation focusing on and planning for the right objectives. Strategies should not be developed in a vacuum. They must be responsive to the external environment. If not, an organisation can become irrelevant (Dess et al. 2008:37). The Synod report on 'Maintenance and growth of the church' (Vergeer 2000: [assignment 3, point 2.4]) states that the specific circumstances and environment of the congregation should be analysed and considered when crafting and executing a congregational strategy. The subjective copying of other congregations and how they have executed a strategy in the past, without careful consideration of the circumstances of the specific date and place, is not true to its biblical calling. A thorough and scientific analysis of the environment in which the congregation exists and functions is supported by sound theory on Strategic Management as well as the unique character of a congregation.

\section{Best practice 4}

We have learned from others how to approach the process (e.g. we studied books on Strategic Management in congregations) or make use of external facilitators. Strategic Management is a scientific process consisting of analysis, decisions and actions (Dess et al. 2008:8). The process of Strategic Management has various phases. At a high level there are two phases, namely, the crafting or formulating of the strategy and the execution and evaluation of the strategy (David 2005:5). Strategic management not only focuses on achieving short-term targets, but also incorporates longterm perspectives (Dess et al. 2008:8). In a congregation, it should also be a long-term process ( $\mathrm{Nel}$ 2006:31) in which the different phases are not skipped because it can create confusion and resistance instead of mission fulfilment (Nel 1994:148). Growing and maintaining the congregation will require long-term plans. Burger, Meiring, Van Niekerk and Wepener (2005:168) emphasise that the process should be approached and conducted with continuous prayer.

\section{Best practice 5}

Spend enough time before you commence with the process explaining it to the congregation members. In the traditional Afrikaans mainstream churches it is not uncommon for members to be hesitant to embrace the principle of Strategic Management (Nel 2006:200). But with the many challenges a congregation faces, it should not refrain from taking up the challenge to do Strategic Management. Strategic Management is a means to an end and not the end itself. Thus, it is good practice to rather begin slower and engage as many people as practically possible (ibid.:178). 


\section{Lessons learned from implementing a congregational strategy}

The empirical study highlighted some valuable lessons learned by congregations during the crafting and execution of their congregational strategy. The lessons learned are also supported by the literature on Strategic Management (Grobler 2010:135). The most dominant of these aspects are listed below:

\section{Aspect 1}

The process commenced with only a small number of people participating, leading to non-participation of the majority of the members. Thirty-four of the 48 congregations indicated that their Strategic Management process was not inclusive enough. Strategies must ensure that the work of the congregation is done not only by people in specific positions, such as the minister, elder or deacon. Strategies must ensure that all believers are willing and able to employ their God-given talents in God's Kingdom, and that they are not sidelined and become passive and immature (Vergeer 2000: [assignment 3, point 2.4.15]). It is the responsibility of the senior management team in an organisation to do strategic planning; they cannot delegate this function to staff or support officials (Kotze 2007:7). However, although senior management has the accountability for strategic planning, it should be an inclusive process. It is important to involve as many managers and key leaders as possible in the strategic planning process, because through involvement, people become committed (David 2005:55).

\section{Aspect 2}

Ten of the respondents indicated that the time span for crafting their strategy was too short. This is an important lesson learned that should be incorporated into any Strategic Management model for a congregation because Strategic Management not only focuses on achieving short-term targets, but also incorporates long-term perspectives (Dess et al. 2008:8). Without long-term objectives, an organisation would drift aimlessly towards some unknown end (David 2005:159). Callahan (1990:246) warns that nobody should think that developing and growing a congregation is quick or easy. Growing and maintaining the congregation will require long-term plans. If the time span for planning is too short, confusion between operational planning and strategic planning may exist, which will make both sciences ineffective.

\section{Aspect 3}

In Aspect 1 it was indicated that some congregations experienced difficulty because too few members were involved. On the other extreme, seven congregations indicated that much time was wasted because they wanted to involve all members of the congregation before proceeding. Although the crafting of the vision and mission must be an inclusive process by involving as wide a group of leaders as possible, it is not practical to involve everybody in the organisation during the debating, exploring and crafting of the vision and mission. Thus, sufficient communication regarding the strategic process must be ensured to prevent people from feeling excluded.

\section{Aspect 4}

The process did not adequately recognise the difference between a congregation and other organisations, leading to an ineffective Strategic Management process. The church is primarily invisible and spiritual by nature and is not limited to specific nations, countries, cultures or languages. The institutional character of a church and the congregation is not the primary focus (Van Wyk 2001:39). The local congregations of the RCSA are independent, although they function as complete churches as required in the Bible by preaching the gospel, serving the sacraments and applying discipline as required by God (Spoelstra 1989:6). Burger (1999:16) reminds congregations that their work should not primarily be to build the congregations themselves, but to build the Kingdom of God. This unique character must be recognised when practicing Strategic Management in the congregation. Seven of the respondents indicated that their Strategic Management process did not take this uniqueness sufficiently into account. The aim of Strategic Management in a congregation should not be on what is best for the congregation, but what God wants to do with and through the congregation (Nel 1994:113).

\section{Framework for crafting and executing a congregational strategy}

Matthew 28:18 makes it clear that everything in heaven and on earth is subject to the authority of Jesus Christ. This includes the knowledge man has of science. In the crafting and execution of a congregational strategy, it is advisable for the congregation to adhere to the principles of the science of Strategic Management.

The empirical study indicated that knowledge of the process of Strategic Management is a stumbling block for many congregations that have a congregational strategy. Table 1 is a proposed framework that can be used by a congregation in the crafting and executing of their congregational strategy. It is based on the five-phased approach as described by Thompson et al. (2007:20), but the actions and questions are aimed at a congregation's circumstances.

\section{Approach to a congregational strategy}

The institutional character of a congregation should never be the primary focus. It is thus important to realise that a congregational strategy is only a means to an end, and not the end itself. Before embarking on strategy sessions, it must be communicated and clearly understood that crafting and executing a congregational strategy is only a systematic and structured approach whereby a congregation can understand its work in the Kingdom of God, given their specific circumstances. Burger et al. (2005:167) state that with a congregational strategy it should not be the congregation 
TABLE 1: Summary framework for a congregational strategy.

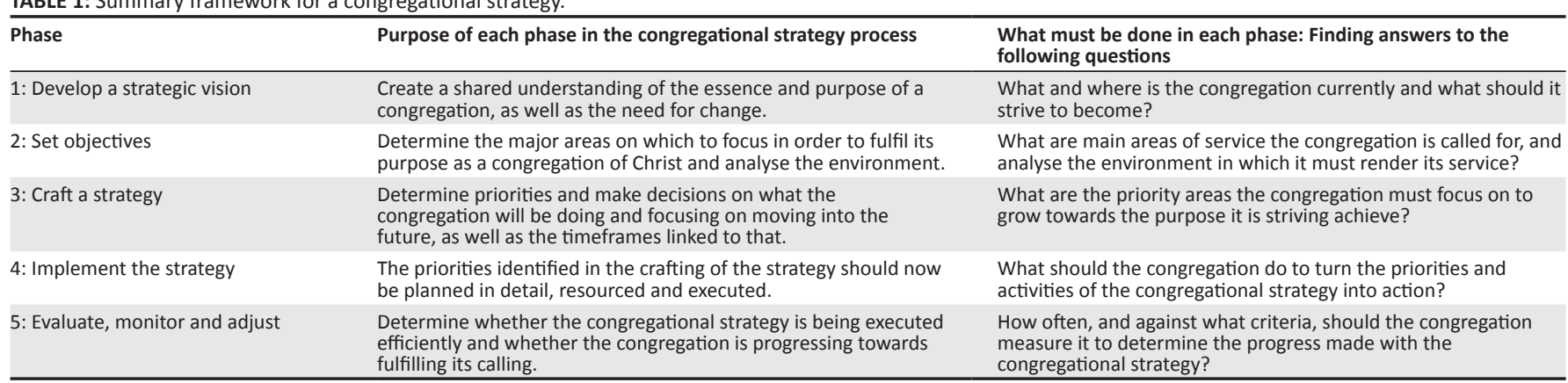

Source: Grobler, A.B., 2010, 'A framework for crafting and implementing a congregational strategy in the local congregations of the Reformed Churches of South Africa', Ph.D. Thesis in Business Administration, North-West University, Potchefstroom

Continuous prayer and guidance of the Holy Spirit, as well as continuous communication and change management are applicable to all categories.

that plans and works and the Holy Spirit who helps them. It should rather be the Holy Spirit who works and the congregation that should find their role in the planning and execution of this holy work.

J.L. van der Walt (2009:264) emphasises that a mind-shift and creativity are of great importance when planning for the future of the congregation, just as church reformers such as Luther and Calvin had to make mind-shifts in their time. Whilst a worldly organisation will try to create as much value as possible for its members, the church's assignment will be to continuously reform to the expectations of Christ, the Head of the church. The key to the success of the congregational strategy lies in the work of the Holy Spirit, not in models, structures or a vision (Kruger 2007:97). Burger et al. (2005:168) emphasise that the process of crafting and executing a congregational strategy should be approached and conducted with continuous prayer.

Strategic management is a scientific process consisting of various phases that are planned and executed over a number of years. In a congregation, it should also be a process (Nel 1994:113) in which the different phases are not skipped or else it can create confusion and resistance instead of mission fulfilment (ibid.:148). The growth and maintenance of the congregation will require long-term thinking and planning.

Various reasons for initiating a congregational strategy in a congregation were mentioned by the respondents of the empirical study. Factors such as a financial crisis, the merger of two congregations into one, serious incidents of racism or discomfort with not fulfilling its purpose, initiated congregations to think strategically about their future. The calling of a congregation into God's Kingdom is too comprehensive and important to be conducted in a haphazard way. Thus, it is advisable that a congregational strategy should be crafted and executed before a crisis forces a congregation to do so.

\section{Components of the congregational strategy process}

More detail on the actions to be executed during each phase of the congregational strategy model will be dealt with in a follow-up article. Below is a high-level summary of each phase.

\section{Phase 1: Develop a strategic vision}

Purpose of this phase: The purpose of this phase is to create a common understanding amongst congregation members of the biblical purpose of the congregations, the work of the congregation and the role of the congregation given its own unique time and location. In the empirical study, the wrong view of what a congregation is was indicated as a major stumbling block for the successful execution of a congregation's calling. Having a shared understanding of the essence and work of a congregation is the first step in developing a strategic vision. If this is not clear, the congregation might be efficient (doing things right) but ineffective (doing the wrong things). Without a clear understanding of the purpose and calling of the congregation there would be no reason for the congregation to move towards it.

What must be done during this phase?: It would be incorrect to begin the crafting of a congregational strategy with a potential list of detailed plans and activities to be executed. During this phase of the congregational strategy, there are three things that should firstly, be determined:

1. Mission statement. An organisation's mission statement clarifies the character of the organisation and its reason for existence. A congregation's reason for existence is not something that can simply be decided upon. Through continuous prayer and Bible study, the congregation must receive a shared understanding of who they are and why they are here, given their specific geographic location and place in time. Burger (1999:52) puts it strongly when he indicates that his biggest concern with the church is when congregations lose sight of their identity and are not clear in answering the question: 'Who are we?' A correct view of the reason for existence, or a mission statement, is fundamental to any activities and actions planned in the church (Nel 1994:145). The question to answer is: 'What is a congregation that is true to its purpose?'

2. Vision statement. Any organisation's vision statement should provide the answer to the question: 'What do we want to become?' A vision is necessary so that everybody in the congregation can know and understand the direction of the congregation in future (Kruger 2007:61). Without a vision, a congregation runs the risk of becoming disorderly because members and activities might 
work against each other. In the empirical study, 73\% of congregations that implemented Strategic Management indicated that spending ample time on formulating a shared vision for the congregation reduced time spent on debating and working on less important issues (Grobler 2010:99). The question to answer is: 'What should the congregation strive to become?'

3. Determine the strategic gap. Van Wyk (2001:145) emphasises that a true church should continuously reform itself to its calling in the Bible. The congregation should continuously examine and test itself (2 Cor 13:5-6). This self-examination is essential for meaningful growth to take place in a congregation. They should not try to evade the consequences of understanding the effects of the vision and mission (B.J. van der Walt 2009:25). In the empirical study, $77 \%$ of the congregations that implemented Strategic Management indicated that this thorough self-examination energised and activated the congregation towards action in closing the gap between their current state and what Christ required from them. An understanding and desire to change should be created or else no change will take place. The question to answer is: 'How far did the congregation develop towards its true purpose and destination?' and 'Is there agreement that there is a need for the congregation to grow towards closing the gap between what the congregation is now and where it should be?'

\section{Phase 2: Set objectives}

Purpose of this phase: After having a shared understanding of the congregation's mission (what they are), vision (where they are heading) and the strategic gap (understanding the difference of where they are and where they should be), the next phase is to determine the congregation's objectives (what they should be doing). The emphasis during this phase should be on effectiveness (keeping themselves busy with the right things) and not on efficiency (detailing plans and activities on how to do things correctly). There should be a direct relation between the vision (where they are heading), the mission (what they are) and the objectives they set to pursue (what they should be focussing on) (Burger et al. 2005:19). Objectives should be the main areas of action that should be focussed on in order to be true to the essence of the congregation (mission) and to reach their goal (vision) (Grobler 2010:161).

What must be done during this phase?: Analysis and exploration is a feature of this phase. This is not the stage in which detailed plans and activities should be discussed. During this phase, there are mainly two things that must be explored:

1. Determine the objectives of a balanced congregation. Through continuous prayer and under guidance of the Holy Spirit, a congregation should understand what the objectives are that a true congregation should aspire to fulfil. Clarity on its objectives is very important for a congregation, otherwise everybody will have their own perceptions as to whether the congregation is fulfilling its calling or not (Warren 2007:37). The setting of objectives to ensure that the congregation directs balanced attention to its full calling is an integral part of strategic planning, and without it a congregation runs the risk of being untrue to its calling. A congregation that, for example only focuses on internal issues and does not pursue the objective of spreading the gospel outside the congregation boundaries, is not fulfilling its calling (Van Wyk 2001:81). Nel (1994:187) argues that the objectives of a congregation should be to reflect God's will. Furthermore, the objectives should be achievable and measurable, and there should be a balance between the maintenance and growth command.

2. Analysis of the congregation's circumstances. Kruger (2007:17) uses the words of Jesus in Mark 1:17, when He called the disciples to 'fish for people' to illustrate what the nature of the work of the church in the world outside the congregation should be. The external environment has a huge influence on the manner in which this is carried out. For example, the methods applied for sea fishing versus river fishing differ. Droughts, floods and even regulatory requirements require adaptation from fishermen. The same applies to the church's assignment to 'fish for people'. External influences might influence the way a congregation fishes, but it must continue with the work. Understanding and describing God's field (1 Cor 3:9) is important information for a congregation in order to effectively plan and execute its work. Thus, it is important for a congregation to analyse and understand the external environment in which God has placed it.

No two congregations are exactly the same, even if they belong to the same reformed family of churches. Congregations function and exist in different places and contexts. The spiritual gifts as indicated in 1 Corinthians 12:7 will differ from one congregation to another. The specific attributes and gifts of the congregation should be analysed and considered when crafting and executing a congregational strategy. The subjective copying of what other congregations did, or what was done in the past, is not true to its biblical calling (Vergeer 2000:[point 2.4.13]). Congregations should embrace and use their strengths to move forward, but they should also acknowledge their weaknesses and face them constructively.

\section{Phase 3: Crafting the congregational strategy}

Purpose of this phase: The understanding created by describing the mission and vision as well as the analysis described above, leads us to plan the way forward in great detail. Because of the overwhelming amount of data available from the previous phases, the prioritisation of actions as well as the setting of a timeline for execution will be critical. Embarking on too many activities will divide focus and resources, and will lead to an activity trap; embarking on too few activities will cause stagnation and loss of interest. Embarking on the wrong initiatives will lead to the congregation not fulfilling its calling. The purpose of this phase is to make decisions on what will be done on the way forward, as well as the timeframes linked to that. God never intended that activities in his church should happen in an unorganised and undisciplined manner. Thus, good planning under the guidance of the Holy Spirit is necessary. 
What must be done during this phase?: All congregations must have a systematic plan with which to build the church (Vergeer 2000: [point 2.4.14]). Once all the information from the process described above is available, the congregation has the obligation to plan the way forward to maintain and grow the church, otherwise the congregation will not function in an orderly manner. Without all the facts available from the analysis, plans and actions will be based on perceptions (Nel 1994:156). This implies a plan that is executed over an extended period of time and that will not happen in a few months. It is important to understand the magnitude of the work that a congregation needs to do, but it is also necessary not to try and do everything at once (Warren 2007:59). Thus, to achieve the objectives, priorities must be established of what needs to be done and the sequence in which they must be done. The congregation should be careful of two things when realising all the opportunities and threats facing them. On the one hand, the congregation might be tempted to try and tackle everything at once. On the other hand, a congregation might be overwhelmed to such an extent by the magnitude of the work that they do not do anything (Burger et al. 2005:35).

In the process of crafting the congregational strategy, much can be learned from other congregations and denominations (Warren 2007:42). However, because the situation and variables will differ from one congregation to another, not one strategy will look exactly the same (Burger 1999:300). Thus, the subjective copying of the strategy of another congregation should not be done (Vergeer 2000: [point 2.4.16]).

\section{Phase 4: Implementation of the congregational strategy}

Purpose of this phase: Even if the congregation's strategy is not perfect, but is actually implemented, it will achieve more than the perfect plan that never gets off the ground. The priorities identified in the crafting of the strategy should now be planned in detail, resourced and executed. Every step the congregation takes should be in the faith that God will provide what is needed for the congregation to fulfil its purpose.

What should be done during this phase?: An important reality is that not only the strategy itself, but also the execution of the strategy should be planned carefully. The question to be answered is: 'What should the congregation do to turn the priorities of the congregational strategy into deeds?'

At this stage, various individuals, small groups, commissions, committees and meetings will have the responsibility to plan and execute a broad spectrum of activities. Good operations management, financial management, project management and other management and individual skills will now be needed. However, from a Strategic Management perspective, the total picture should be monitored. The execution of the strategy will differ from one congregation to the next because no congregation's strategy and action plan will be the same. However, the following list of focus areas are generic items that should receive attention as part of the implementation phase of any strategy (Thompson et al. 2007:361):

1. Develop abilities and talents of congregation members. In Ephesians 4:12, Christ commands that the gifts in the congregation should be developed and employed in God's Kingdom. Without the development of gifts, fewer of the congregation members will be able to assist in the execution of the congregation's calling. The question to ask is: 'How can the gifts and talents in the congregation be developed and employed?'

2. Align structures and processes to support the congregational strategy. Structures should always be in support of the congregation's strategy to fulfil its calling. Structures include, amongst others, meeting structures, workgroups and committees, reporting structures and communication channels. The question to answer is: 'What structures should be in place in the congregation to support the fulfilling of its calling as set out in the congregational strategy?'

3. Finding and allocating resources. God will provide what is necessary for a congregation to fulfil its calling. The allocation of resources should be balanced between the different objectives the congregation sets out to achieve. Resources include, amongst others, finances, buildings, agenda, time of meetings, leadership, talents and people's time. Because resources are normally scarce, prioritisation should take place to ensure that all objectives are properly resourced over the long term. The question to answer is: 'In what way should the available resources be allocated to facilitate the execution of the balanced objectives of the congregation as set out in the congregational strategy?'

4. Adopt best practice and continuous improvement. The congregation functions in a dynamic world and, consequently, what worked well in the past will not necessarily work well in the future. The question to answer is: 'What practices were identified that can be adopted from other congregations that will make our congregation more efficient and effective in the execution of the congregational strategy?'

5. Rewards and encouragement. In a worldly organisation, monetary incentives are given when activities in support of the organisation's strategy are executed well. This is used to encourage the right behaviour in order to gain momentum with the strategy execution process. These types of rewards and incentives are not applicable in a congregation. However, in 1 Thessalonians 5:11, Christians are reminded that they should encourage each other, especially when they employ their talents and gifts as stated in 1 Peter 4:10. An important part of implementing the congregational strategy will be to answer the following question: 'How can we create opportunities for congregation members to build relations and encourage one another to employ their gifts and talents?'

6. Congregational culture alignment. Organisational culture can be defined as a system of shared goals (what is important) and beliefs (how things work). The culture develops over many years and has a decisive influence 
on the way the organisation functions. Even if everybody agrees that the strategies and plans are the correct ones, they will not turn into action if they are in conflict with the culture in the congregation. The closer the bond between the culture in the congregation, and the objectives and strategies to be executed, the higher the probability that the plans will turn into action. If the culture in the congregation is such that it does not support the plans to be executed, the probability that the plans will turn into action is small. An important part of implementing the congregational strategy will be to align the culture in the congregation to support the plans and strategies to be executed. The question to answer is: 'What is the current culture in the congregation (perception of what is important and how we do things) and does it align with what is needed to turn the congregational strategy into action?'

7. Strong leadership to drive strategy execution. Good leadership is a determining factor for a congregation's success. Different situations require different responses from leaders to successfully lead the situation. The leadership role should not only rest on one or two people's shoulders, and leadership should also not be limited to certain offices, for example, the minister and the elders. Given the needs required by the congregational strategy, the leadership talents of faithful men and woman of all ages must be developed and employed. As part of the execution of the strategy, the development and empowerment of many leaders should be a focus area. The question to ask is: 'In what way can sufficient leadership capacity be developed and utilised to successfully execute the congregational strategy?'

\section{Phase 5: Evaluate, monitor and adjust the congregational strategy}

Purpose of this phase: Congregations are not successful when they do well with normal organisational goals, such as money, membership numbers or grand events; they are successful when they fulfil their God-given calling. Thus, a congregation should continuously monitor and evaluate itself against criteria set earlier in the design of the congregational strategy. The purpose is to determine whether the congregational strategy is being executed and whether it progresses toward fulfilling the congregation's calling. Timely evaluation can alert the congregation to problems or potential problems before the situation becomes critical. If the evaluation indicates the need for changes in the congregational strategy itself or the execution of the strategy, the necessary steps for change must be initiated.

What should be done during this phase?: Continuous monitoring and evaluation should take place over various aspects and with various frequencies. If a congregation is not clear on what the criteria are for measuring its progress, it will tend to measure its progress against the wrong criteria, such as membership growth, financial assets or number of projects initiated. This will lead to the wrong perceptions, thereby resulting in wrong decision-making. The congregation should continuously examine and test itself (2 Cor 13:5-6), not only at the beginning of the Strategic Management process, but also on a continuous basis.

\section{Conclusion}

There is a definite need for congregations to have a clear strategy on how to conserve and build the church. The majority of congregations in the RCSA are not able to craft a congregational strategy because of a lack of knowledge and skills regarding the process. Thus, it is recommended that congregational leaders, and in particular ministers, be educated in this management science. This can be done by including a course on Strategic Management in the training syllabus of aspirant ministers. It is recommended that the RCSA give consideration to employing a consultant who can assist the local congregations because of the advantages an external Strategic Management consultant will bring to crafting and executing a strategy. Most of the congregations of the RCSA do not have the financial resources to hire an external consultant at their own cost.

\section{Acknowledgements Competing interests}

The authors declare that they have no financial or personal relationship(s) which may have inappropriately influenced them in writing this article.

\section{Authors' contributions}

A.B.G. (North-West University) was resposible for the reseach. J.L.v.d.W. (North-West University) was the promoter and B.J.d.K. (North-West University) was the assistant promoter.

\section{References}

Burger, C., 1999, Gemeentes in die kragveld van die Gees, Lux Verbi, Stellenbosch.

Burger, C., Meiring, L., Van Nieker, A. \& Wepener, C., 2005, Waar die kerk werk, Lux Verbi, Wellington.

Callahan, K.L., 1990, Effective church leadership: Building on the twelve keys, HarperCollins Publishers, New York.

Collins, J., 2001, Good to great: Why some companies make the leap and others don't, Harper Collins Publishers, New York.

Daniell, M., 2004, Strategy: A step-by-step approach to the development and presentation of world class business strategy, Palgrave Macmillan, Hampshire.

David, F.R., 2005, Strategic Management, 10th edn., Pearson Prentice Hall, Upper Saddle River.

Dess, G.G., Lumpkin, G.T. \& Eisner, A.B., 2008, Strategic Management, 4th edn., McGraw-Hill, New York.

Garrison, R.H., Noreen, E.W. \& Brewer, P.C., 2006, Managerial Accounting, 11th edn., McGraw-Hill, New York.

Grobler, A.B., 2010, 'A framework for crafting and implementing a congregational strategy in the local congregations of the reformed churches of South Africa', Ph.D. Thesis in Business Administration, North-West University.

Kotze, J., 2007, Study guide for Strategic Management (MPTP 876 ET), Potchefstroom, North-West University.

Kruger, F., 2007, Jy is die kerk: Leiersgids, Gereformeerde Kerk, Middelburg-Noord.

Nel, M., 1994, Gemeentebou, Perskor Drukkers, Midrand.

Nel, M., 2006, Stories van hoop, Christelike Uitgewersmaatskappy (CUM), Vereeniging. 
Osmer, R.R., 2008, Practical theology: An introduction, Eerdmans, Grand Rapids.

Smit, C.J., 2008, 'Is die kerkorde nie kragtens sy aard strydig met die werking van die Heilige Gees nie?', In die Skriflig 42(3), 393-408.

Smit, C.J., 2009, 'Kan die GKSA na 150 jaar beskou word as 'n stagnante kerkgemeenskap?', In die Skriflig 43(3), 447-471.

Spoelstra, B., 1989, Gereformeerde kerkreg en kerkregering, V\&R Drukkery, Pretoria.

Stern, C.W. \& Deimler, M.S., 2006, The Boston Consulting Group on strategy, John Wiley Sons Inc., Hoboken.

Thompson, A.A., Strickland, A.J. \& Gamble, J.E., 2007, Crafting and executing strategy: The quest for competitive advantage, 15th edn., McGraw-Hill, New York.

Ungerer, M., 2009, 'Strategic success: Elusive dream or a real possibility?', Business Brief 14(6).

Van der Walt, B.J., 2009, 'Probleme rondom die verklaring van die Bybel in die gereformeerde teologie: 'n Christelike-filosofiese besinning', In die Skriflig 43(1), 1-30.
Van der Walt, J.L., 2009, 'Spirituality the "new" religion of our time?', In die Skriflig 43(2), 251-289.

Van Rooy, J.A., 2007, 'Kan die Gereformeerde Kerke hoegenaamd nog met die Evangelie uitreik?', Kerkblad 109(3197), 39-41.

Van Wyk, J.H., 2001, Kerk en Christen-wees vandag, Potchefstroom Teologiese Publikasies, Potchefstroom.

Vergeer, W.C., 2000, 'Report regarding the maintenance and growth of the church', Report delivered at the 2000 synod meeting of the GKSA held in Potchefstroom, viewed 07 January 2007, from http://www.gksa.org.za/sinode2000.html

Vorster, J.M., 1996, Is die kerk funksioneel? Gedagtes oor Gereformeerde kerkvernuwing in'n post-moderne konteks, Potchefstroom Teologiese Publikasies, Potchefstroom.

Warren, R., 2007, Die doelgerigte kerk: Groei sonder om jou boodskap of roeping prys te gee, 2de uitg., Struik Christelike boeke, Kaapstad.

Wiebes, E., Marc, B., Keibek, B. \& Witteveen, P., 2007, The craft of strategy formulation: Translating business issues into actionable strategies, John Wiley \& Sons Ltd., West Sussex. 